\title{
The Compliance of 3D Scanned Anthropometric Data with a CAD Grafis Measurement Chart
}

\author{
Ausma Vilumsone', Inga Dabolina², \\ ${ }^{1,2}$ Institute of Design Technologies, Riga Technical University
}

\begin{abstract}
The designing of clothes includes a row of processes and one of the most time and labor consuming is constructing. The construction displays the layout (pattern) of the surface of the body (garment). In order to exclude routine job from the pattern making process CAD Systems are used. To gain a good construction, exact, proper and accurate human body measurements are needed. Measurements acquired by 3D scanning device should be checked out for compliance with CAD systems for automatized pattern making procedure.
\end{abstract}

Keywords - 3D anthropometry, anthropometric data, CAD systems, pattern making.

\section{INTRODUCTION}

The usage of garment designing systems excludes the time consuming manual preparation of patterns, creation of layouts and relocation of written information. Although computer systems significantly facilitate the development of a product, the knowledge and skills of the user are still very important. One of the most important garment creation stages is constructing.

The aim of this research is to check out compliance of 3D scanned anthropometric data with a CAD Grafis measurement chart.

\section{DESCRIPTION OF THE DATA PROCESSING SYSTEMS AND METHODOLOGY USED FOR PATTERNMAKING}

To conform and check the compliance of 3D scanned anthropometric data with a CAD Grafis measurement chart, it is necessary to create a table in order to construct a sample and to verify measurements obtained and usability of them in CAD Grafis. 3D scanning system VITUS Smart XXL, CAD system Grafis and Pattern making system M. Müller \& Sohn are used for this purpose. The methodology of measurement system of M. Müller \& Sohn pattern making system is compared with the scanner measurement acquisition methodology.

\section{A. 3D Scanning System}

Anthropometric data can be acquired with different tools. Traditional methods use different manual tools (measuring tape, anthropometer, etc.). As the technologies develop, new tools are created and/or the existent ones are improved. A relatively new tool (approximately since 1980 (1)) in anthropometry is the 3D scanner.

Considering the advantages of 3D scanning, the scanning technologies are being developed and improved. Most of the scanners can not only create a 3D image of the human body, but also read the $x, y$ and $z$ coordinates thereby acquiring precise information about the human body and its volumes (2).
VITUS Smart XXL used in RTU IDT is a 3D body scanner designed to generate highly precise 3-dimensional images of the human body according to the ISO 20685.

This technology can be utilized for a variety of applications in fields as serial measurements and military working clothes. VITUS Smart XXL is based on optical triangulation, currently the most accurate method for touchless 3D imaging (3).

\begin{tabular}{|l|l|}
\hline File ERAFIS - Edit measurement charts \\
\hline \\
\hline
\end{tabular}

Fig. 1. Measurements used in CAD Grafis M. Müller \& Sohn.

\section{B. CAD System}

Computer aided designing software not only provides the possibility to speed up the process of putting a new model into production and improve the quality of the products, but also to reduce material costs and labor intensity, ensuring an elastic 
change of the assortment. Most of the systems are made by the module principle in which separate garment designing stages are implemented (4).

GRAFIS is CAD software for pattern design and marker making. It offers creation and modification of pattern pieces, grading and output to printers and plotters as well as export of the finished pattern in several data formats. In addition GRAFIS contains a marker making software, which enables the placement of the completed styles and subsequent plotting. Export to cutters is also possible. GRAFIS is used in industry, craft and schools.

GRAFIS works with the construction principle as a standard procedure. Body measurement charts are used to draft basic blocks which are then modified into styles and production patterns. These measurement charts can represent standard sizes and/or individual sizes. The structure of the measurement charts depends on the measurement system. The interactive basic blocks delivered with the Grafis software relate to the measurement charts (5).

\section{Pattern System M. Müller \& Sohn}

The principles of the pattern making system M. Müller \& Sohn are as follows - the pattern system M. Müller \& Sohn is based on the construction system with proportional calculation. This pattern system takes into account different figure proportions exactly (6). Modified patterns are created from basic pattern blocks.
The advantages of the pattern system M. Müller \& Sohn are:

- Fit for standard sizes as well as for made-to-measure.

- Pattern development in the building block principle: existing basic patterns can be modified.

- Development of design variations from the same basic pattern.

- Variable use of ease additions.

- Applicably for CAD-computer aided design.

Pattern system M. Müller \& Sohn is integrated into CAD system Grafis. Fig. 1 shows the example of Measurement Chart for German system women's size 38.

\section{ANTHROPOMETRIC DATA}

There are two types of human body measurement acquiring methods: manual anthropometry methods (contact methods); optic anthropometry methods (non-contact methods).

\section{A. Acquiring of the Data}

To ascertain the compliance of 3D scanned anthropometric data with a CAD Grafis measurement chart respondents (nine women aged $20-30$ ) were chosen. The summary of the necessary measurements, the acquired measures from the automated scanner and 3D anthropometrics are given in Table I.

TABLE I

COMPARISON OF BODY MEASUREMENT LIST AND THE RESUlT OF 3D SCANNING FOR TARGET GROUP

\begin{tabular}{|c|c|c|c|c|c|c|c|c|c|c|c|c|c|}
\hline \multicolumn{2}{|c|}{$\begin{array}{c}\text { System M. Müller } \\
\text { \& Sohn }\end{array}$} & \multicolumn{2}{|c|}{$\begin{array}{c}\text { ANTHROSCAN } \\
\text { automatic measurements } \\
\text { (standard posture) }\end{array}$} & \multirow[t]{2}{*}{ Description } & \multirow[t]{2}{*}{$\mathbf{A}$} & \multirow[t]{2}{*}{ B } & \multirow[t]{2}{*}{$\mathbf{C}$} & \multirow[t]{2}{*}{ D } & \multirow[t]{2}{*}{$\mathbf{E}$} & \multirow[t]{2}{*}{$\mathbf{F}$} & \multirow[t]{2}{*}{$\mathbf{G}$} & \multirow[t]{2}{*}{$\mathbf{H}$} & \multirow[t]{2}{*}{ I } \\
\hline ID & Name & ID & Name & & & & & & & & & & \\
\hline $01 \mathrm{Kh}$ & Height & 0010 & Body Height & $\begin{array}{l}\text { Vertical height from standing } \\
\text { surface to the visual top of the } \\
\text { head. The vertical distance is } \\
\text { measured between the standing } \\
\text { surface and the top of the head. }\end{array}$ & 169.8 & 160.8 & 169.1 & 173.8 & 170.6 & 168.4 & 161.9 & 175.2 & 168.4 \\
\hline $02 \mathrm{Bu}$ & $\begin{array}{l}\text { Bust } \\
\text { girth }\end{array}$ & 4510 & $\begin{array}{l}\text { Bust/chest } \\
\text { girth } \\
\text { (horizontal) }\end{array}$ & $\begin{array}{l}\text { The circumference of the chest is } \\
\text { measured across the bust point } \\
\text { landmarks. The circumference is } \\
\text { measured parallel to the standing } \\
\text { surface. }\end{array}$ & 95.0 & 103.4 & 93.2 & 89.8 & 88.1 & 97.1 & 93.4 & 98.6 & 86.9 \\
\hline $03 \mathrm{Tu}$ & $\begin{array}{l}\text { Waist } \\
\text { girth }\end{array}$ & 6510 & Waist Girth & $\begin{array}{l}\text { The circumference of the waist is } \\
\text { measured in the height of the } \\
\text { natural waist (if feasible). The } \\
\text { natural waist height is } \\
\text { determined by extracting a } \\
\text { contraction point on the side. } \\
\text { The circumference is measured } \\
\text { parallel to the standing surface. }\end{array}$ & 69.8 & 82.8 & 70.4 & 75.9 & 69.9 & 70.7 & 77.0 & 80.4 & 64.5 \\
\hline $04 \mathrm{Hu}$ & Hip girth & 7520 & $\begin{array}{l}\text { Buttock } \\
\text { Girth }\end{array}$ & $\begin{array}{l}\text { The circumference of the buttock } \\
\text { is measured in a front-to-back } \\
\text { plane with the tape passing just } \\
\text { above the most protruding point } \\
\text { of the buttock. The } \\
\text { circumference is measured } \\
\text { parallel to the standing surface. }\end{array}$ & 92.8 & 112.1 & 98.3 & 99.9 & 96.6 & 93.1 & 102.1 & 106.2 & 86.7 \\
\hline 05 Hsu & $\begin{array}{c}\text { Base of } \\
\text { neck }\end{array}$ & 1520 & $\begin{array}{c}\text { Neck at Base- } \\
\text { Girth }\end{array}$ & $\begin{array}{c}\text { Circumference measurement at } \\
\text { the level of the base of the neck, } \\
\text { just on the transition between } \\
\text { torso and neck. }\end{array}$ & 36.8 & 38.7 & 38.5 & 40.6 & 35.3 & 35.0 & 39.2 & 40.6 & 35.4 \\
\hline $06 \mathrm{Hs}$ & $\begin{array}{l}\text { Neck } \\
\text { width }\end{array}$ & & & $\begin{array}{l}\text { Determined as proportion from } \\
\text { neck circumference }\end{array}$ & & & & & & & & & \\
\hline
\end{tabular}




\begin{tabular}{|c|c|c|c|c|c|c|c|c|c|c|c|c|c|}
\hline \multicolumn{2}{|c|}{$\begin{array}{c}\text { System M. Müller } \\
\text { \& Sohn }\end{array}$} & \multicolumn{2}{|c|}{\begin{tabular}{|c|} 
ANTHROSCAN \\
automatic measurements \\
(standard posture)
\end{tabular}} & \multirow[t]{2}{*}{ Description } & \multirow[t]{2}{*}{$\mathbf{A}$} & \multirow[t]{2}{*}{ B } & \multirow[t]{2}{*}{$\mathbf{C}$} & \multirow[t]{2}{*}{ D } & \multirow[t]{2}{*}{$\mathbf{E}$} & \multirow[t]{2}{*}{$\mathbf{F}$} & \multirow[t]{2}{*}{$\mathbf{G}$} & \multirow[t]{2}{*}{$\mathbf{H}$} & \multirow[t]{2}{*}{ I } \\
\hline ID & Name & ID & Name & & & & & & & & & & \\
\hline $07 \mathbf{R h}$ & $\begin{array}{l}\text { Nape to } \\
\text { scye }\end{array}$ & $\mathbf{5 0 3 0}$ & \begin{tabular}{|c|} 
Neck to \\
across back \\
width \\
(armpit level)
\end{tabular} & $\begin{array}{c}\text { Vertical measurement over the } \\
\text { back from the 7CV landmark to } \\
\text { the (mid) level of the posterior } \\
\text { armpits. }\end{array}$ & 15.9 & 22.1 & 15.1 & 15.6 & 14.8 & 14.7 & 13.6 & 17.3 & 14.8 \\
\hline 08 Rl & $\begin{array}{l}\text { Nape to } \\
\text { waist }\end{array}$ & 5040 & $\begin{array}{c}\text { Neck to } \\
\text { center waist } \\
\text { back }\end{array}$ & $\begin{array}{c}\text { Measurement between the nape } \\
\text { (7CV) landmark and the waist } \\
\text { girth (code 6510) tape on the } \\
\text { back. }\end{array}$ & 39.9 & 37.2 & 38.9 & 41.3 & 38.0 & 38.9 & 35.2 & 37.5 & 39.1 \\
\hline $09 \mathrm{Ht}$ & $\begin{array}{l}\text { Nape to } \\
\text { hip }\end{array}$ & 0040 & $\begin{array}{c}\text { Distance } \\
\text { neck to hip }\end{array}$ & $\begin{array}{c}\text { Vertical height between the nape } \\
\text { landmark and the level of the } \\
\text { buttock girth (code 7520) }\end{array}$ & 59.3 & 53.9 & 60.8 & 60.8 & 57.0 & 57.1 & 54.9 & 56.9 & 60.1 \\
\hline 10 Rlg & $\begin{array}{c}\text { Skirt } \\
\text { length }\end{array}$ & & & Should be chosen by user & & & & & & & & & \\
\hline 11 Bt II & $\begin{array}{c}\text { Shoulder } \\
\text { to bust }\end{array}$ & $\begin{array}{l}4080 \\
4081\end{array}$ & $\begin{array}{c}\text { Bust point to } \\
\text { neck left } \\
\text { Bust point to } \\
\text { neck right }\end{array}$ & $\begin{array}{c}\text { Measurement between the neck } \\
\text { base at side to the bust point } \\
\text { landmark. }\end{array}$ & $\begin{array}{l}25.5 \\
25.6\end{array}$ & $\begin{array}{l}28.5 \\
28.6\end{array}$ & $\begin{array}{l}28.4 \\
27.6\end{array}$ & $\begin{array}{l}28.6 \\
28.1\end{array}$ & $\begin{array}{l}26.7 \\
26.5\end{array}$ & $\begin{array}{l}29.1 \\
28.1\end{array}$ & $\begin{array}{l}26.8 \\
26.5\end{array}$ & $\begin{array}{l}28.2 \\
27.2\end{array}$ & $\begin{array}{l}25.5 \\
25.5\end{array}$ \\
\hline 12 VI II & $\begin{array}{c}\text { Shoulder } \\
\text { to waist } \\
\text { over bust }\end{array}$ & 4040 & $\begin{array}{c}\text { Neck right to } \\
\text { waist over } \\
\text { bust }\end{array}$ & $\begin{array}{c}\text { Measurement between the neck } \\
\text { base at side (right) via the bust } \\
\text { point (right) landmark to the } \\
\text { waist level (6510). }\end{array}$ & 45.5 & 42.1 & 45.5 & 43.3 & 42.7 & 47.2 & 40.1 & 41.5 & 43.6 \\
\hline $13 \mathbf{R b}$ & $\begin{array}{l}\text { Across } \\
\text { back }\end{array}$ & 5020 & $\begin{array}{c}\text { Across Back } \\
\text { width } \\
\text { (armpit level) }\end{array}$ & $\begin{array}{c}\text { Horizontal measurement over the } \\
\text { body surface from armpit } \\
\text { landmarks on the back left to } \\
\text { right. }\end{array}$ & 38.1 & 35.5 & 32.6 & 34.8 & 33.3 & 38.8 & 34.0 & 38.1 & 34.6 \\
\hline 14 Ad & $\begin{array}{c}\text { Scye } \\
\text { width }\end{array}$ & $\begin{array}{l}8910 \\
8911\end{array}$ & \begin{tabular}{|c|} 
Upper arm \\
diameter left \\
Upper arm \\
diameter \\
right \\
\end{tabular} & $\begin{array}{l}\text { Horizontal distance between } \\
\text { front and back armpits on the } \\
\text { side. }\end{array}$ & $\begin{array}{l}10.4 \\
11.6\end{array}$ & $\begin{array}{l}13.0 \\
13.0\end{array}$ & $\begin{array}{l}10.6 \\
10.7\end{array}$ & $\begin{array}{l}10.2 \\
9.9\end{array}$ & $\begin{array}{l}9.3 \\
8.9\end{array}$ & $\begin{array}{l}9.7 \\
9.2\end{array}$ & $\begin{array}{l}9.8 \\
9.7\end{array}$ & $\begin{array}{l}10.9 \\
11.2\end{array}$ & $\begin{array}{l}8.3 \\
8.7\end{array}$ \\
\hline $15 \mathrm{Bb}$ & $\begin{array}{c}\text { Across } \\
\text { bust }\end{array}$ & 4020 & $\begin{array}{c}\text { Width } \\
\text { Armpits }\end{array}$ & $\begin{array}{c}\text { Horizontal Measurement over } \\
\text { the body surface from armpit } \\
\text { landmarks left to right across the } \\
\text { front of the chest. }\end{array}$ & 38.3 & 46.8 & 34.8 & 34.5 & 40.0 & 42.1 & 36.8 & 42.3 & 34.4 \\
\hline 16 Schb & Shoulder & $\begin{array}{l}3030 \\
\mathbf{3 0 3 1}\end{array}$ & $\begin{array}{c}\text { Shoulder } \\
\text { width left } \\
\text { Shoulder } \\
\text { width right } \\
\end{array}$ & $\begin{array}{l}\text { Measurement from the neck base } \\
\text { landmark at the side to the } \\
\text { acromion point landmark. }\end{array}$ & $\begin{array}{l}11.6 \\
11.5\end{array}$ & $\begin{array}{l}11.5 \\
11.4\end{array}$ & $\begin{array}{l}11.8 \\
11.7\end{array}$ & $\begin{array}{l}12.4 \\
12.3\end{array}$ & $\begin{array}{l}12.7 \\
12.8\end{array}$ & $\begin{array}{l}12.5 \\
11.7\end{array}$ & $\begin{array}{l}10.7 \\
9.6\end{array}$ & $\begin{array}{l}12.3 \\
12.2\end{array}$ & $\begin{array}{l}11.6 \\
11.6\end{array}$ \\
\hline 17 Aelg & \begin{tabular}{|c|} 
Arm \\
length \\
from \\
acromion
\end{tabular} & $\begin{array}{l}8030 \\
8031\end{array}$ & $\begin{array}{l}\text { Arm length } \\
\text { left } \\
\text { Arm length } \\
\text { right }\end{array}$ & $\begin{array}{c}\text { The distance is measured from } \\
\text { the top of the acromion point, } \\
\text { then along the elbow landmark to } \\
\text { the wrist landmark. }\end{array}$ & $\begin{array}{l}55.2 \\
56.2\end{array}$ & $\begin{array}{l}60.7 \\
60.9\end{array}$ & $\begin{array}{l}57.5 \\
57.3\end{array}$ & $\begin{array}{l}59.5 \\
62.3\end{array}$ & $\begin{array}{l}60.2 \\
60.2\end{array}$ & $\begin{array}{l}60.3 \\
59.4\end{array}$ & $\begin{array}{l}59.2 \\
57.8\end{array}$ & $\begin{array}{l}63.5 \\
64.5\end{array}$ & $\begin{array}{l}56.2 \\
55.9\end{array}$ \\
\hline 18 Obu & $\begin{array}{l}\text { Upper } \\
\text { arm } \\
\text { girth }\end{array}$ & $\begin{array}{l}8520 \\
8521\end{array}$ & $\begin{array}{l}\text { Upper Arm } \\
\text { Girth Left } \\
\text { Upper Arm } \\
\text { Girth Right }\end{array}$ & $\begin{array}{l}\text { Circumference measurement } \\
\text { perpendicular to an upper arm } \\
\text { axis on the biceps muscle. }\end{array}$ & $\begin{array}{l}26.2 \\
26.1\end{array}$ & $\begin{array}{l}33.6 \\
33.2\end{array}$ & $\begin{array}{l}28.5 \\
29.1\end{array}$ & $\begin{array}{l}27.3 \\
27.1\end{array}$ & $\begin{array}{l}26.5 \\
25.9\end{array}$ & $\begin{array}{l}25.8 \\
24.9\end{array}$ & $\begin{array}{l}28.3 \\
27.2\end{array}$ & $\begin{array}{l}29.7 \\
30.1\end{array}$ & $\begin{array}{l}22.8 \\
23.1\end{array}$ \\
\hline $19 \mathrm{Hgu}$ & $\begin{array}{l}\text { Wrist } \\
\text { girth }\end{array}$ & $\begin{array}{l}8550 \\
8551 \\
8555\end{array}$ & $\begin{array}{l}\text { Wrist Girth } \\
\text { left } \\
\text { Wrist Girth } \\
\text { right } \\
\text { Wrist girth } \\
\end{array}$ & $\begin{array}{l}\text { Perimeter measured at the arm } \\
\text { extremity just before the } \\
\text { transition to the hand. }\end{array}$ & $\begin{array}{l}14.4 \\
15.2 \\
14.8\end{array}$ & $\begin{array}{l}15.4 \\
15.5 \\
15.4\end{array}$ & $\begin{array}{l}15.3 \\
15.0 \\
15.2\end{array}$ & $\begin{array}{l}15.7 \\
15.0 \\
15.4\end{array}$ & $\begin{array}{l}14.6 \\
14.8 \\
14.7\end{array}$ & $\begin{array}{l}14.5 \\
14.2 \\
14.3\end{array}$ & $\begin{array}{l}14.3 \\
14.1 \\
14.2\end{array}$ & $\begin{array}{l}15.9 \\
15.6 \\
15.7\end{array}$ & $\begin{array}{l}14.9 \\
14.6 \\
14.7\end{array}$ \\
\hline 20 Stl & $\begin{array}{c}\text { Waist to } \\
\text { floor }\end{array}$ & $\begin{array}{l}9035 \\
9036\end{array}$ & $\begin{array}{l}\text { Sideseam at } \\
\text { waist left } \\
\text { Sideseam at } \\
\text { waist right }\end{array}$ & $\begin{array}{l}\text { Length measurement from the } \\
\text { outer side of the foot on the } \\
\text { standing surface to the most side } \\
\text { point of the waist circumference } \\
\text { (code 6510) measurement. }\end{array}$ & $\begin{array}{l}107.1 \\
106.9\end{array}$ & $\begin{array}{l}103.4 \\
102.9\end{array}$ & $\begin{array}{l}107.0 \\
106.9\end{array}$ & $\begin{array}{l}110.4 \\
110.9\end{array}$ & $\begin{array}{l}108.9 \\
109.5\end{array}$ & $\begin{array}{l}107.9 \\
108.0\end{array}$ & $\begin{array}{l}107.3 \\
107.3\end{array}$ & $\begin{array}{l}116.5 \\
116.5\end{array}$ & $\begin{array}{l}105.9 \\
105.7\end{array}$ \\
\hline $21 \mathrm{Lbh}$ & Body rise & \begin{tabular}{|l|}
$9035 / 9036-$ \\
$9020 / 9021$ \\
\end{tabular} & & Should be calculated & 29 & 28.5 & 32 & 29.3 & 29 & 27 & 30.3 & 31.5 & 30.5 \\
\hline 22 Schr & $\begin{array}{c}\text { Inside } \\
\text { leg }\end{array}$ & $\begin{array}{l}9020 \\
9021\end{array}$ & $\begin{array}{c}\text { Inseam left } \\
\text { Inseam right }\end{array}$ & $\begin{array}{l}\text { The distance is measured from } \\
\text { the inner side of the foot on the } \\
\text { standing surface to the lowest } \\
\text { point of the crotch.. The subject's } \\
\text { feet are placed in footprints } \\
\text { adhered to the standing surface. }\end{array}$ & $\begin{array}{l}77.8 \\
78.0\end{array}$ & $\begin{array}{l}74.8 \\
74.3\end{array}$ & $\begin{array}{l}74.9 \\
75.0\end{array}$ & $\begin{array}{l}81.3 \\
81.3\end{array}$ & $\begin{array}{l}80.0 \\
80.1\end{array}$ & $\begin{array}{l}80.9 \\
81.0\end{array}$ & $\begin{array}{l}76.8 \\
77.0\end{array}$ & $\begin{array}{l}85.5 \\
84.7\end{array}$ & $\begin{array}{l}75.2 \\
75.4\end{array}$ \\
\hline $23 \mathrm{Knu}$ & $\begin{array}{l}\text { Ankle } \\
\text { girth }\end{array}$ & $\begin{array}{l}9550 \\
9551\end{array}$ & $\begin{array}{l}\text { Ankle Girth } \\
\text { Left } \\
\text { Ankle Girth } \\
\text { Right } \\
\end{array}$ & $\begin{array}{c}\text { Horizontal perimeter measured at } \\
\text { the height of the anklebone. The } \\
\text { circumference is measured } \\
\text { parallel to the standing surface. }\end{array}$ & $\begin{array}{l}22.5 \\
22.3\end{array}$ & $\begin{array}{l}24.1 \\
24.0\end{array}$ & $\begin{array}{l}22.8 \\
23.0\end{array}$ & $\begin{array}{l}25.3 \\
25.2\end{array}$ & $\begin{array}{l}23.1 \\
24.0\end{array}$ & $\begin{array}{l}23.1 \\
23.2\end{array}$ & $\begin{array}{l}22.2 \\
22.7\end{array}$ & $\begin{array}{l}26.7 \\
27.0\end{array}$ & $\begin{array}{l}23.9 \\
24.1\end{array}$ \\
\hline
\end{tabular}


3D scanning has several advantages compared to manual measurements - it is fast, sequential, and has a higher precision level. Using 3D scanning no professional knowledge is needed to acquire the measurements - most of the systems generate the measures of the human body self-dependently.

\section{B. Data Analysis}

Before the scanning experiment, measurements were made manually; by comparing the data, it was concluded that the deviations are within the acceptable range in accordance with the standard ISO 20685 if the measured person has no major defects of posture. Almost all circumferences 3D scan data while processed are set accurately horizontally (parallel to the surface of the man standing), but manual measurements only apply to the horizontal direction. For example, waist circumference (ID 6510), the circumference is measured in the height of the natural waist (if feasible) above the pelvic bone. In the case of pelvic asymmetry this measurement is carried out manually at an angle, while the automated 3D measurement system is carried horizontally, thus it is not possible to determine the appropriate measurement (see Fig. 2.).

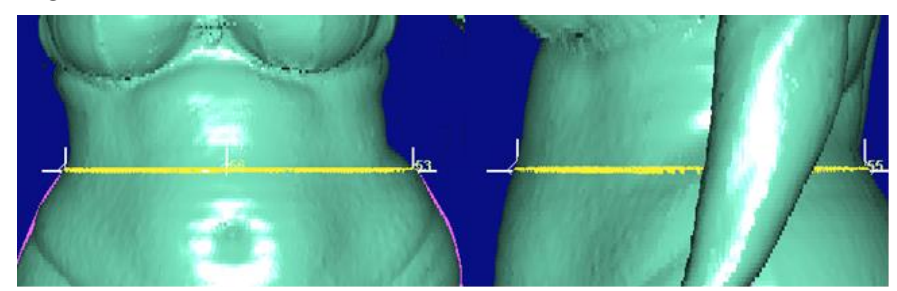

Fig. 2. Sample of scanned body surface with asymmetrical body sides for measurement ID 6510 Waist Girth.

With other important measurements there are similar problems in the case of asymmetry.

TABLE II

COMPARISON OF THE RESUlTS OF MANUAL MEASUREMENTS AND Automatic 3D MEASUREMENTS FOR ACROSS Front MEASUREMENT

\begin{tabular}{|c|c|c|c|}
\hline$\#$ & $\begin{array}{c}\mathbf{1 5} \text { Bb Across } \\
\text { bust (cm) }\end{array}$ & $\begin{array}{c}\text { 4020 Width } \\
\text { Armpits (cm) }\end{array}$ & Difference (cm) \\
\hline A & 28 & 38.3 & 10.3 \\
\hline B & 38 & 46.8 & 8.8 \\
\hline C & 34.5 & 34.8 & $\mathbf{0 . 3}$ \\
\hline D & 34 & 34.5 & $\mathbf{0 . 5}$ \\
\hline E & 33 & 40 & 7.0 \\
\hline F & 38 & 42.1 & 4.1 \\
\hline G & 37 & 36.8 & $\mathbf{- 0 . 2}$ \\
\hline H & 36 & 42.3 & 6.3 \\
\hline I & 34 & 34.4 & $\mathbf{0 . 4}$ \\
\hline
\end{tabular}

In some cases a horizontal cross-cutting plane is not an appropriate measure of the distance measurements, such as the measurement across the front (4020 Width armpits) is measured as the Horizontal Measurement over the body surface from armpit landmarks left to right across the front of the chest, but compared to manual measurement results the differences are significant (see Table II).
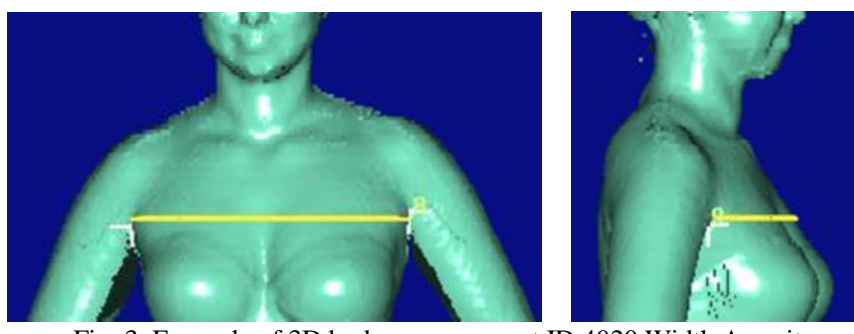

Fig. 3. Example of 3D body measurement ID 4020 Width Armpits.

Across front measurement obtained in 3D scanner is not usable for tailoring needs, although it is measured from one armpit to the other armpit (see Fig. 3), the result is not read by the shortest surface distance, but along the perimeter of the horizontal plane.

In addition, the study found that the difference is not dependent on the size of the target group, namely the absence of a correlation between the human body girth measured values and ID 4020 with the measurement across bust (see Table II). However, there is a strong correlation with breast location and size. Higher placement of breasts sets larger horizontal measurement, and the difference between manually and automatically derived measurements is greater (see Table III).

TABLE III

COMPARISON OF TRANSVERSAL PLANES ON ARMPIT LEVEL

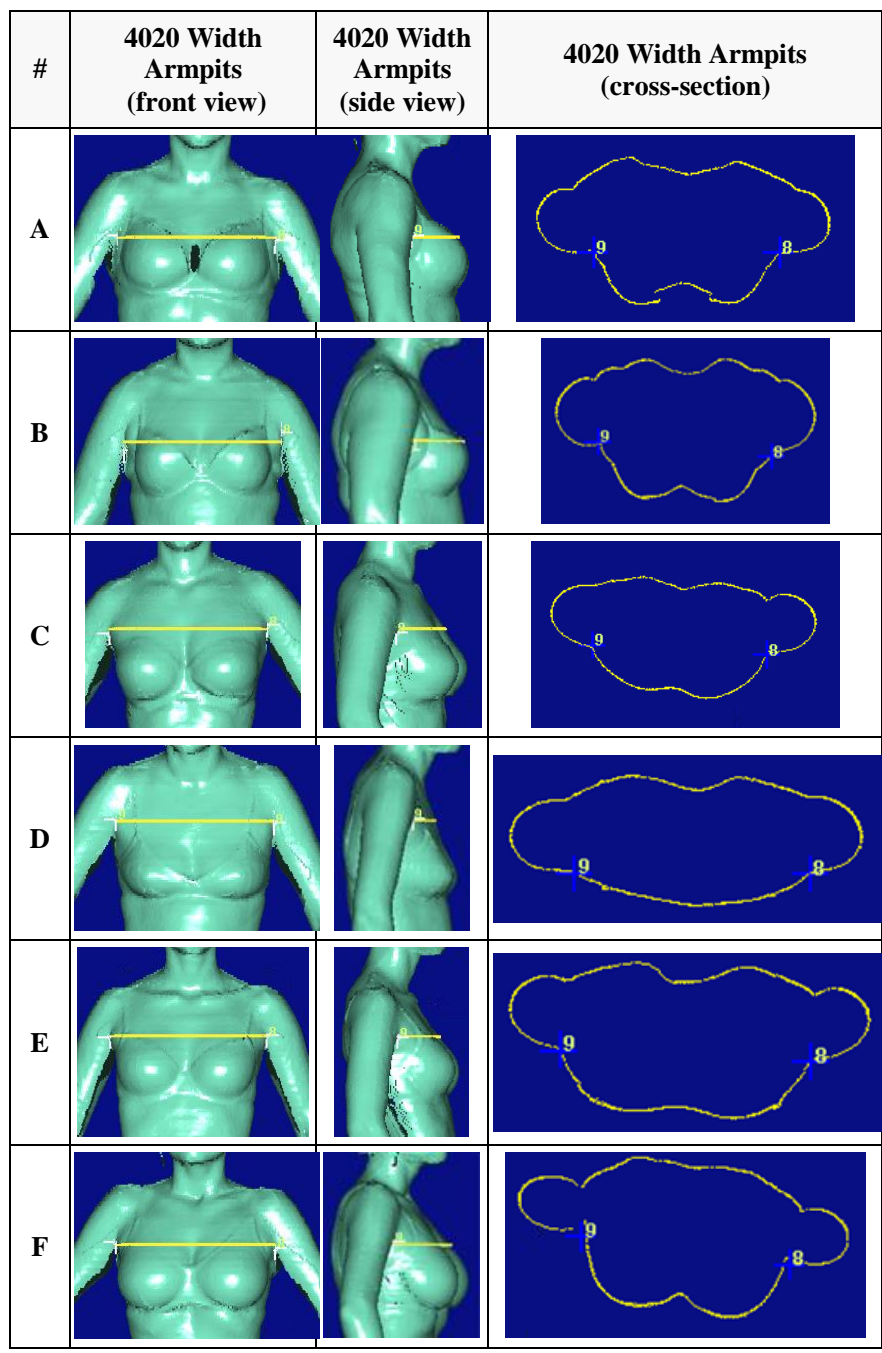




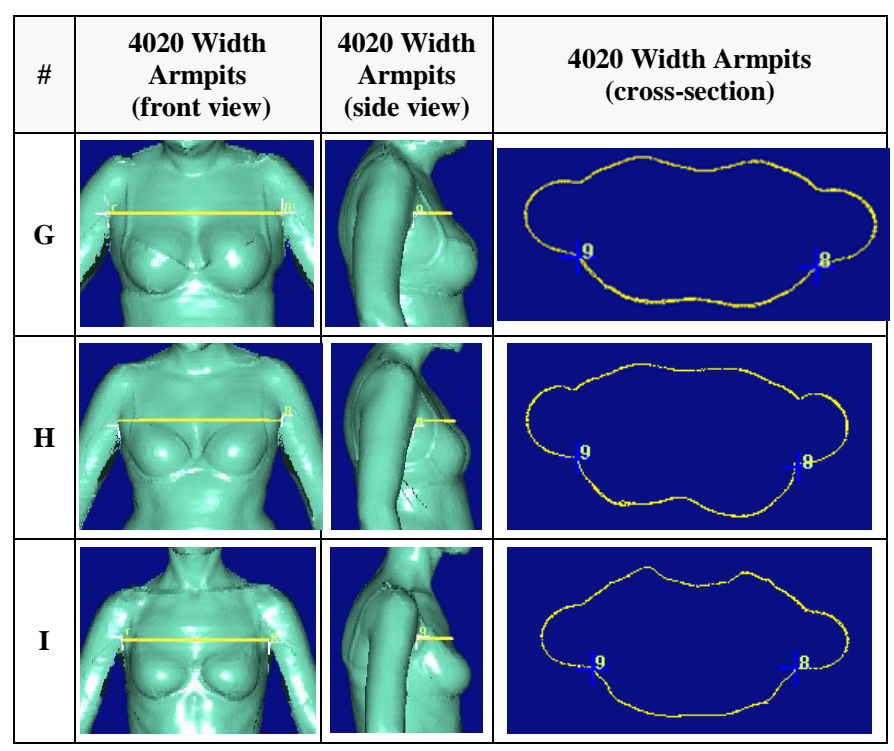

It is obvious, the more shaped and curved is the transversal cross-sectional plane the higher the measurement is obtained. It can be explained by the fact that the measurement is obtained when directly measured horizontally along the surface contour at armpit level, instead of finding the shortest path between the two anthropometric points.

\section{Automatic PATTERNMAKING}

For automated verification of the acquired measurement CAD Grafis individual patterns are created. The measurements obtained from 3D scanner placed into CAD Grafis measurement chart (see Fig. 1) are compared with the corresponding standard measures. Basic pattern blocks have been chosen according to the pattern making system chosen and ease allowances have been added afterwards (see Table IV).

\section{TABLE IV}

EASE VALUES CHOSEN FOR INDIVIDUAL PATTERNS IN COMPARISON WITH THE RANGE RECOMMENDED BY SYSTEM

\begin{tabular}{|c|c|c|}
\hline Ease allowance & $\begin{array}{c}\text { Recommended } \\
\text { range (mm) }\end{array}$ & $\begin{array}{c}\text { Allowance } \\
\text { used (mm) }\end{array}$ \\
\hline Across back width & $(10-15)$ & 12 \\
\hline Scye & $(30-40)$ & 35 \\
\hline Across front width & $(15-20)$ & 17 \\
\hline Shoulder & --- & 10 \\
\hline Waist girth & $(50-100)$ & 70 \\
\hline Hip girth & $(30-60)$ & 40 \\
\hline
\end{tabular}

As shown in Table IV, none of the values used exceeds the recommended range. Fig. 4 shows the design of an individualized set up and I B samples compared with the corresponding standard block pattern and created the design layouts.
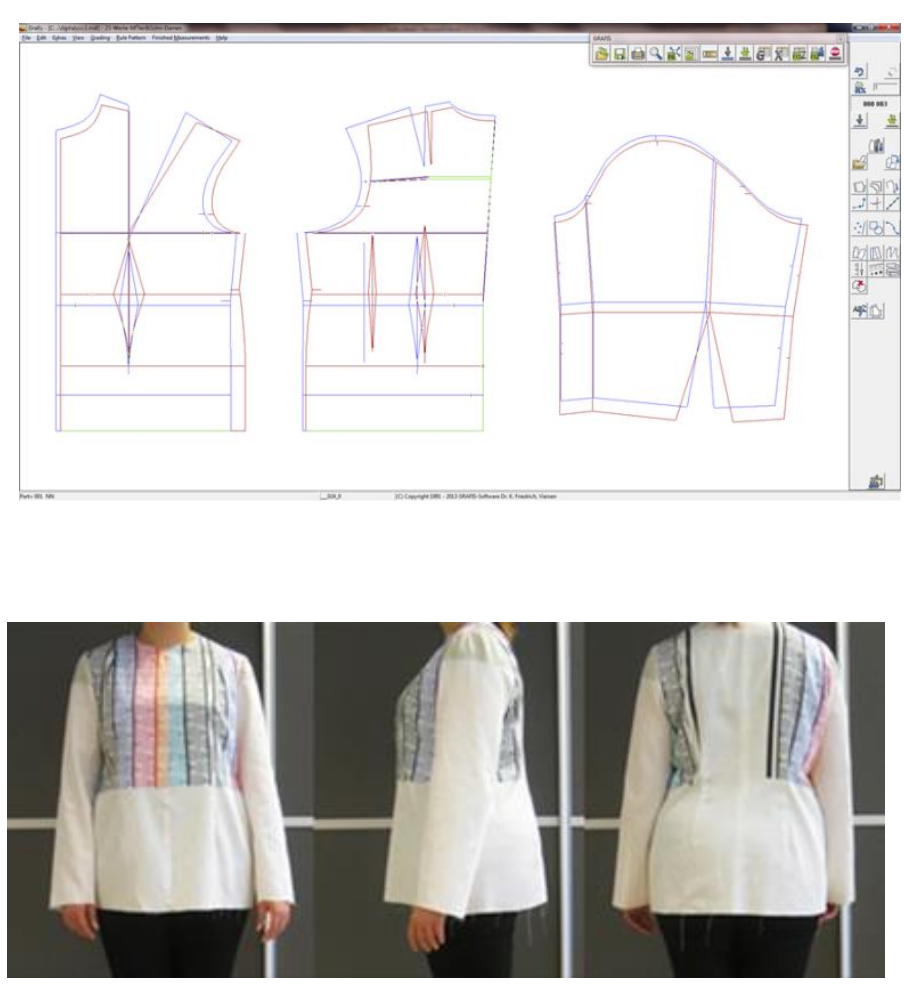

Sample B
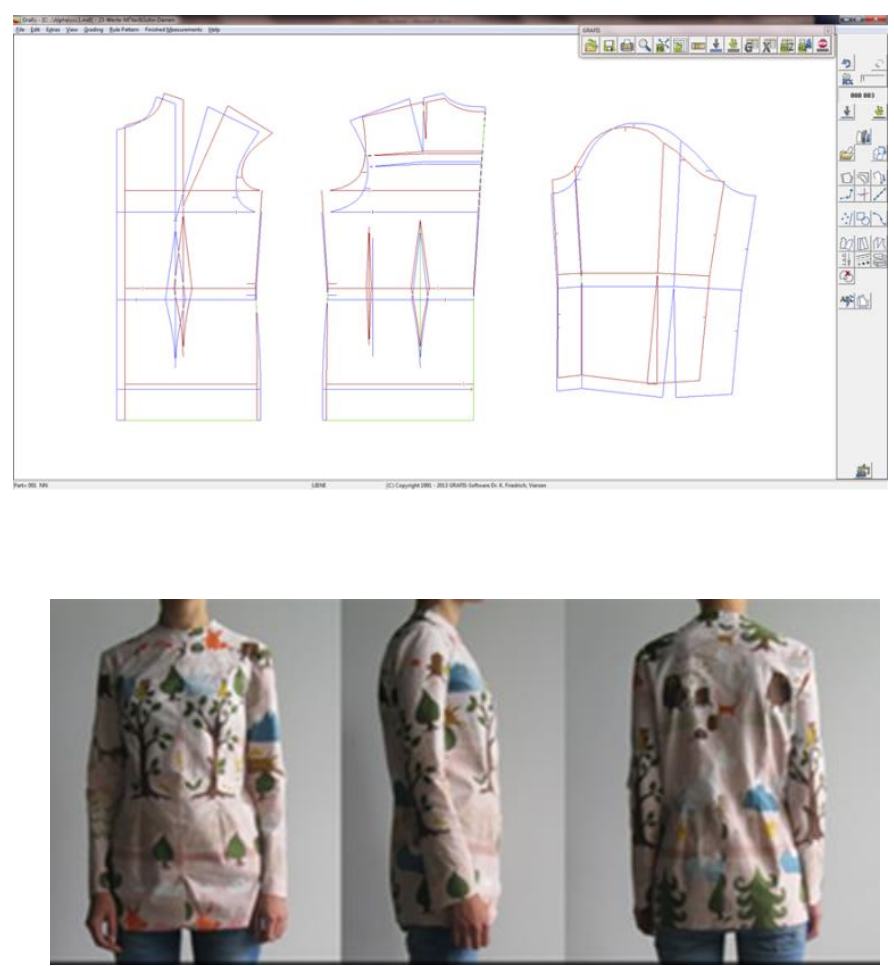

Sample I

Fig. 4. B and I samples and constructions in comparison with standard pattern blocks. B is for size 024 and I for size 038 . 


\section{CONCLUSION AND FUTURE WORK}

Currently existing procedure when from more than hundred human body measurements obtained one should select the required twenty three measurements is a tedious routine work where the initial findings should be treated with numeric array processing program then manually placed in CAD Grafis table. In order to fully use the obtained 3D anthropometric data and to insert them into fully automated CAD Grafis table, during further research it is necessary to develop a special devoted software.

Computer aided clothing designing and anthropometric data acquisition possibilities available for use, systems and methods have been studied and analyzed in the paper. The possibilities of 3D human body scanning have been studied, identified and systemized, characteristics have been given and an analysis of possible combining has been performed.

\section{REFERENCES}

1. Fan, J., Yu, W., Hunter, L. Clothing appearance and fit: Science and technology. Cambridge, England: Woodhead Publishing Limited, 2004, p. 240. ISBN 0-8493-2594-3. http://doi.org/cctv33

2. Hwang Su-Jeong. Three dimensional body scanning systems with potential for use in the apparel industry. Raleigh, 2001, p. 63.

3. Homepage of Human Solutions GmbH [online]. [viewed 30.06.2014]. Available from: www.human-solutions.com

4. Dāboliņa, I. Anthropometrical Measurements for Three-Dimensional Clothing Design. Synopsis of Doctoral Thesis-R.: RTU, 2010.-35 p.

5. CAD Grafis [online]. [viewed 30.06.2014]. Available from: www.grafis.de

6. Description of Pattern system M. Müller \& Sohn [online]. [viewed 03.09.2014]. Available from: http://muellersohn.com

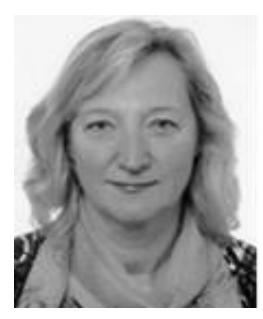

AusmaVilumsone Dr. sc. ing., Professor, Head of the Institute of Design Technologies, Head of the Department of Clothing and Textile Technologies Research interests include the development and optimisation of garment design technological process, CAD/CAM systems in product design, innovative materials and technologies.

Address: Institute of Design Technologies, Riga Technical University, Āzenes Str. 18-215, Riga LV-1048, Latvia.

E-mail: ausma.vilumsone@rtu.lv

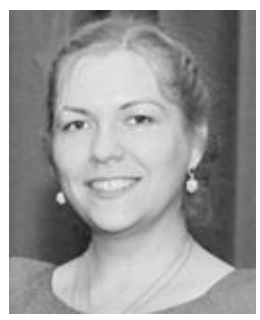

Inga Dabolina Dr. sc. ing., Assistant Professor, Senior Researcher

Research interests include the development and optimization of technological process of garment design, CAD/CAM systems in product design, innovative materials and technologies, 3D body measurements.

Address: Institute of Design Technologies, Riga Technical University, Āzenes Str. 18-220, Riga LV1048, Latvia.

E-mail: inga.dabolina@rtu.lv

\section{Ausma Viḷumsone, Inga Dābolina. 3D skenēto antropometrisko datu atbilstība CAD Grafis mēru tabulai}

Apǵērbu projektēšana iekḷauj sevī virkni procesu, viens no laika, zināšanu un darbietilpīgākajiem procesiem ir konstruēšana. Konstrukcija atspoguḷo nogludinātas cilvēka ḳermeṇa virsmas (apgéērba) izklājumu plaknē (lekāli, piegrieztne). Lai izslēgtu rutīnas darbu, lekālu izstrādes process tiek automatizēts speciālajā̄ CAD sistēmās. Lai iegūtu atbilstošu individualizēto konstrukciju, nepieciešami precīzi, atbilstoši, savstarpēji saistīti cilvēka kermena mēri. 3D skenerī iegūtie antropometriskie dati uzskatāmi par precīziem, tiek iegūti ātri, bez tieša kontakta ar apmērāmo, un vienlaikus visam cilvēka ķermenim. Pirms veiktā skenēšanas eksperimenta, tika veikti manuāli mērījumi, salīdzinot datus, secināts, ka to novirzes ir pieḷajamās robežās atbilstoši standartam ISO 20685, ja mērāmais cilvēks ir bez nozīmīgiem stājas defektiem. Tā kā šāds mēru iegūšanas veids ir salīdzinoši jauns konstruěšanā, ir jāpārbauda 3D skenēto antropometrisko datu atbilstība CAD Grafis mēru tabulai.

Lai saskanotu mēru tabulas un pārbaudītu to atbilstību, ir jāizveido CAD Grafis mēru tabula, lai veiktu maketēšanu un pārbaudītu iegūtos mērus un to lietojamību CAD Grafis. Šādam nolūkam lietota 3D skenēšanas sistēma VITUS Smart XXL, CAD sistēma Grafis un Pattern making system M. Müller \& Sohn, kuras mēru metodika salīdzināta ar skenera mēru iegūšanas metodiku.

Pašreiz esošā procedūra, kad no iegūtajiem vairāk nekā simts cilvēka ķermeṇa mērỉjumiem jāatlasa nepieciešamie divdesmit trīs mēri, ir nogurdinošs rutīnas darbs, kur sākotnēji iegūtie dati jāapstrādā ar skaiț̣u masīvu apstrādes programmu, tad manuāli jāievieto CAD Grafis tabulā. Lai iegūtos 3D antropometrijas datus pilnvērtīgi lietotu un automatizēti ievietotu CAD Grafis tabulā, turpmākajās izstrādēs jāveic atsevišķas programmatūras izveide.

\section{Аусма Вилюмсоне, Инга Даболиня. Соответствие ЗД-сканированных антропометрических данных таблице мерок в САПР ГРАФИС}

Проектирование одежды включает ряд процессов, одной из наиболее трудоёмких работ, требующих специальные знания, является конструирование. Чтобы исключить рутинный труд, разработка лекал автоматизирована в специальных системах САПР. Для получения индивидуальной конструкции необходимы точные, соответствующие, взаимосвязанные размерные признаки фигуры клиента. Мерки, полученные 3Д-сканированием, принято рассматривать как точные антропометрические данные, их получают быстро, без непосредственного контакта с обмеряемым человеком и одновременно для всей фигуры. Перед экспериментом сканирования были мануально сняты измерения, сравнение данных показало, что отклонения в соответствии с ISO 20685 не превышают допустимые границы, если фигура обмеряемого не имеет заметных дефектов. Так как данный способ получения размерных признаков для конструирования сравнительно новый, было необходимо проверить соответствие сканированных антропометрических данных таблице мерок САПР Графис.

Чтобы согласовать таблицы мерок и проверить их соответствие, необходимо создать таблицу мерок САПР Графис, изготовить макет конструкции и проверить полученные размерные признаки и возможность их использования в САПР Графис. С этой целью применялась сканирующая система VITUS Smart XXL, Pattern making system M. Müller \& Sohn в САПР Графис, методика измерения фигуры которой сравнивалась с методикой сканера. Существующая в настоящее время процедура, по которой из более чем ста измерений необходимо отобрать необходимые 23 измерения, является утомительной рутинной работой, где исходные данные обрабатываются программой числовых массивов, далее они мануально вводятся в таблицу САПР Графис. Для полноценного использования ЗД сканированных антропометрических данных и их автоматического ввода в таблицу мерок САПР Графис, в дальнейшем необходимо разработать отдельную программу. 